\title{
The Thermal Encroachment of Microwave Heating with Nano Ferro Fluids Injection on Heavy Oil Deposits
}

\author{
Erdila Indriani ${ }^{1}$, Sudjati Rachmat ${ }^{1}$, Leksono Mucharram $^{1}$, Agus Yodi Gunawan ${ }^{2}$, Munir Achmad $^{3} \&$ Anugerah \\ Solida $^{4}$ \\ ${ }^{1}$ Faculty of Mining \& Petroleum Engineering, Institut Teknologi Bandung, Indonesia \\ ${ }^{2}$ Faculty of Mathematics and Natural Sciences, Institut Teknologi Bandung, Indonesia \\ ${ }^{3}$ School of Electrical Engineering and Informatics, Institut Teknologi Bandung, Indonesia \\ ${ }^{4}$ PetroChina International, Indonesia \\ Correspondence: Erdila Indriani, Faculty of Mining \& Petroleum Engineering, Institut Teknologi Bandung, \\ Indonesia. E-mail: dila_stem@yahoo.com
}

Received: June 6, 2018

doi:10.5539/mas.v12n9p1
Accepted: June 24, 2018 Online Published: August 8, 2018

URL: https://doi.org/10.5539/mas.v12n9p1

\begin{abstract}
Heavy oil demands more energy for its lifting to the surface facilities. A critical parameter that can be altered to enhance the production from the reservoir is the viscosity. Lowering oil viscosity predominantly achieved by thermal methods. This study investigated thermal encroachment in the sand pack layers as simulated heavy oil reservoir was generated by the microwave stack heated mixtures of $22{ }^{0} \mathrm{API}$ of Indonesian heavy crude, nano-ferro fluid $\mathrm{Fe}_{2} \mathrm{O}_{3}$ and saturated brines. The wave guide was used to focus microwave radiation into the sand bed. The experimental results showed that microwave heating with maximum output power of 900 Watt and $\mathrm{Fe}_{2} \mathrm{O}_{3}$ as the nano particles, works at the frequency of $2.45 \mathrm{GHz}$ reduces oil viscosity from $4,412.11 \mathrm{cP}$ on its pour point at $51{ }^{\circ} \mathrm{C}$ to $134.24 \mathrm{cP}$ at $90{ }^{\circ} \mathrm{C}$. Thermal heating with nano ferro fluids decreased the viscosity of heavy oil and make it easier to be flowed. The increases of temperature are directly proportional with power output and nano-ferro concentration.
\end{abstract}

Keywords: heavy oil, viscosity, thermal recovery method, nano-ferro fluid, microwave heating

\section{Introduction}

Abundant amount of heavy oil resources can be one of the alternative solutions to fulfill the world's energy demand. Commonly, heavy and extra-heavy oils are difficult to flow naturally to the wellbore, therefore, they demand more energy for their production. A critical parameter that can be altered to enhance the production from these reservoirs is viscosity. Lowering oil viscosity predominantly achieved by thermal methods (Bera \& Babadagli, 2015). Nowadays, many conventional methods have been applied to decrease heavy oil viscosity, such as steam injection, hot water injection, or gas injection. However, some of those methods have limitation. As instances, steam injection can only be used in shallow reservoir and not permitted to be implementing in offshore. It should have abundant brine supply and hot water system. Others become ineffective due to corrosion problem, significant heat loss and economic criteria. Therefore, developing of heating concept as an alternative to drain additional reserves of heavy crudes is needed. A thermal method that recently attracts many researchers to investigate is electromagnetic heating.

Previous research on heating concept was conducted by Chakma \& Jha, (1992) to understand that electromagnetic (EM) heating is an effective way to introduce energy to the reservoir in control manner and that this energy can be directed into a specific region. Carrizales, et al., (2008) introduced EM heating refers to Radio Frequency (RF) or Microwave (MW) heating, where heating is produced by absorption of electromagnetic energy by the polar molecules in the formation. Pramana, et al., (2012) defined that combination of resistive heating and injection nano ferro fluid are directly related to increase the temperature distribution.

In this research of advanced technology to decrease viscosity of heavy fluid is electromagnetic microwave method with nano-ferro fluid $\mathrm{Fe}_{2} \mathrm{O}_{3}$ as stimulant injection to achieve low viscosity of heavy oil. Microwaves thermal heating was explored as an alternative solution for heavy oil drainage and sand packs and artificial cores have been made to simulate oil deposit sediments. Multiphase fluids (nano-ferro, saturated brines, and heavy crude) then 
saturated into those simulated reservoir samples. The thermal heating of microwave was controlled at $90{ }^{\circ} \mathrm{C}$ and heating exposures recorded in every 20 -sec.

\section{Method}

\subsection{Materials}

Heavy oil origin is from Jatibarang formation, Indonesia. The samples originally were in solid condition and has been liquified at the laboratory at $100{ }^{\circ} \mathrm{C}$ of boiling water in a beaker glass. The oil viscosity, gravity and pour point were measured using water bath viscometer, pycnometer, and a pour point tube, respectively.

The powder nano particles $\left(\mathrm{Fe}_{2} \mathrm{O}_{3}\right)$ supplied by Aldrich Chemistry has size $\leq 50 \mathrm{~nm}$. Sand pack container was made from a modified cylindrical tube Pyrex glass which has $9 \mathrm{~cm}$ in high and $8.56 \mathrm{~cm}$ of inside diameter and equipped with a coned-shape lid. This sand pack mimics the oil reservoir to simulate the reservoir layers. The sandstones grains size was 45-50 meshes supplied by the geology laboratory of Institut Teknologi Bandung. Table 1 presents physical properties of sand pack and the fluids been used in this study.

Table 1. Physical properties of sand pack and the fluids been used in this study

\begin{tabular}{lcc}
\hline \multicolumn{1}{c}{ Properties } & Unit & Experimental results \\
\hline Oil Density & ${ }^{0} \mathrm{API}$ & 22 \\
Crude Viscosity & $\mathrm{cP}$ & 273974.7 \\
$\mathrm{Fe}_{2} \mathrm{O}_{3}$ particles & $\mathrm{nm}$ & 50 \\
Brine & $\mathrm{mg} / \mathrm{ml}$ & 1,024 \\
Sand particles & $\mathrm{mesh}$ & $45-50$ \\
Sand volume & $\mathrm{ml}$ & 250 \\
Brine volume & $\mathrm{ml}$ & 61.6 \\
Nano-ferro volume & $\mathrm{ml}$ & 16 \\
Emulsifier volume & $\mathrm{ml}$ & 2.4 \\
\hline
\end{tabular}

\subsection{Experimental Procedures}

Nano-ferro-fluid was made by mixing hematite powder and brine solution in the sonicator for 20 minutes. In this research, nano-ferro fluids concentration were 10 and $14 \mathrm{ppm}$ to minimize aggregation (Santoso, et al., 2016). This experiment used alternating current to generate voltages. The current voltages then were step up by a transformer before it passed through into the capacitor. The magnetron and microwave antenna transformed the electrical energy into microwaves heating. The maximum income voltage of this concatenation was 1300 watts with maximum outcome voltage was 900 watts. The magnetron has frequency of $2.45 \mathrm{GHz}$ and various power which were 900, 792, 657, and 468 watts. The thermometers have recorded temperature encroachment in the sand pack for every $20 \mathrm{sec}$. Four thermometers were inserted into the Pyrex wall for every $2 \mathrm{~cm}$ distance apart measuring temperature changes which occurred inside the sand pack. The lowest thermometer was tagged as Point-1 and continued up with Point-2, Point-3, and Point-4. However, the observing temperature was limited up to $90{ }^{\circ} \mathrm{C}$ due to water evaporation that might be occurred above $90{ }^{\circ} \mathrm{C}$ (Fig. 1).

In the heating process, two sand packs with different nano- ferro concentration of $10 \mathrm{ppm}$ and $14 \mathrm{ppm}$ were used. The sand pack without nano ferro $(0 \mathrm{wt} . \%)$ was used as the reference sample. Further, the samples were heated by 6 different output powers: $900,792,657,468,378$, and 180 watts. Temperature changes have been recorded for every $20 \mathrm{sec}$ which started at $25{ }^{\circ} \mathrm{C}$ until a point of measurement reached $90{ }^{\circ} \mathrm{C}$. 


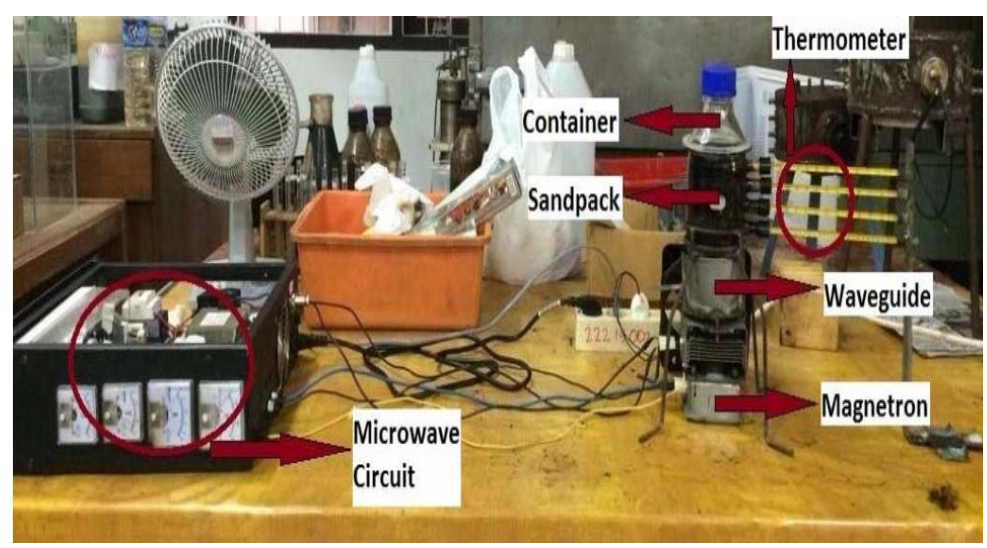

Figure 1. The microwave heating apparatus configuration of microwave heating that has been used in this study

The magnetron and microwave antenna transformed the electrical energy into microwaves heating. The maximum income voltage of this concatenation was 1300 watts with maximum outcome voltage was 900 watts.

\section{Results and Discussion}

The study used nano-ferro fluid with concentration $10 \mathrm{ppm}$ and $14 \mathrm{ppm}$. However, $10 \mathrm{ppm}$ nano-ferro fluid was slower to encroach the heats up to $90{ }^{\circ} \mathrm{C}$ than $10 \mathrm{ppm}$. During the heating, only thermometer at Point- 1 that could reach $90{ }^{\circ} \mathrm{C}$, therefore, all the analysis will use Point- 1 as the reference point. Figure 2 and 3 show temperatures profiles of heats encroachment of microwave heating when the apparatus operated at low and high power, 180 and 900 watts, respectively. At low power 180 watts, the temperatures encroachment increased as the nano-ferro concentration was increased. Similar trends also appeared at high power 900 watts. Temperature changes affected heavy oil viscosity. With this heating process method, heavy oil viscosity has been decreased from $4412.11 \mathrm{cP}$ on its pour point at $51{ }^{\circ} \mathrm{C}$ to $134.24 \mathrm{cP}$ at $90{ }^{\circ} \mathrm{C}$ (Fig. 5).

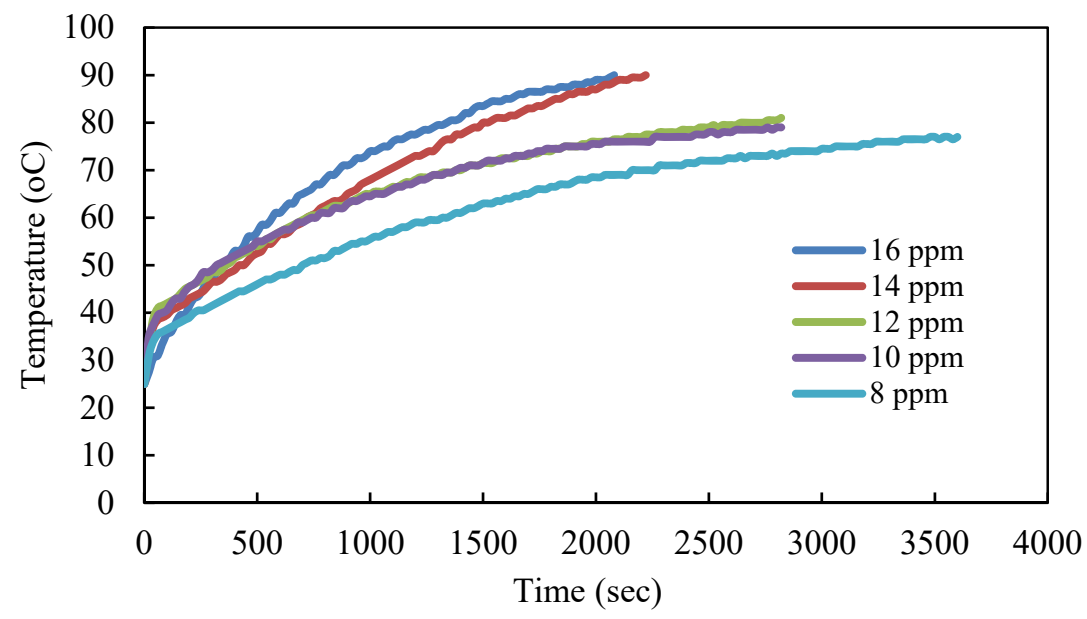

Figure 2. Temperature versus time profile of low power of microwave heating

The power of microwave tuned at 180 watts. However, temperature was limited up to $90{ }^{\circ} \mathrm{C}$ and the concentration of nano-ferro fluid are varied up to $16 \mathrm{ppm}$. 


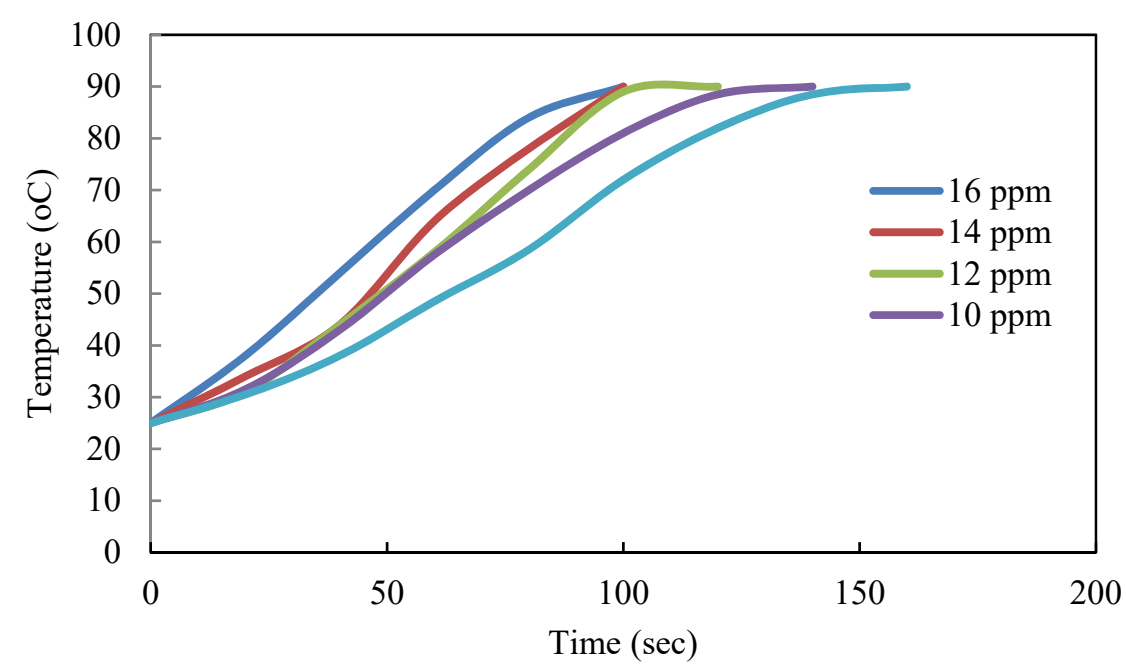

Figure 3. Temperature versus time profile of low power of microwave heating

The power of microwave tuned at 900 watts. However, temperature was limited up to $90{ }^{0} \mathrm{C}$ and the concentration of nano-ferro fluid are varied up to $16 \mathrm{ppm}$

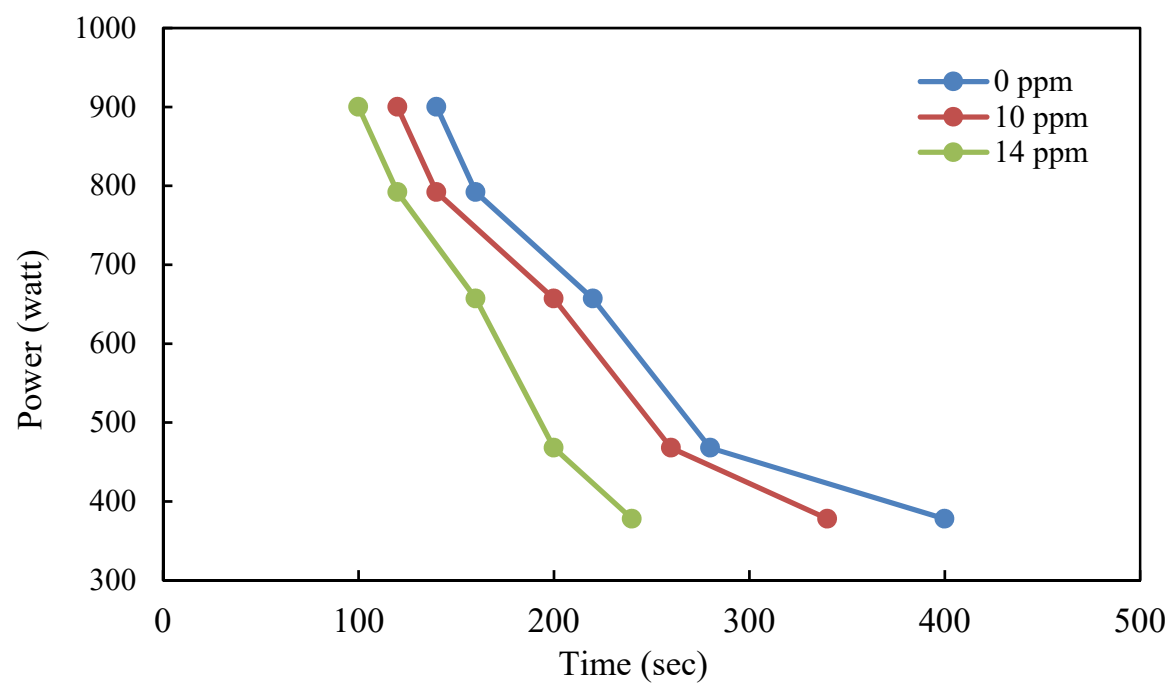

Figure 4. Power of microwave versus time profile of microwave heating

The time to reach a point of heating decreased as the concentration of nano ferro $\mathrm{Fe} 2 \mathrm{O} 3$ was increased, at the certain power of microwave 


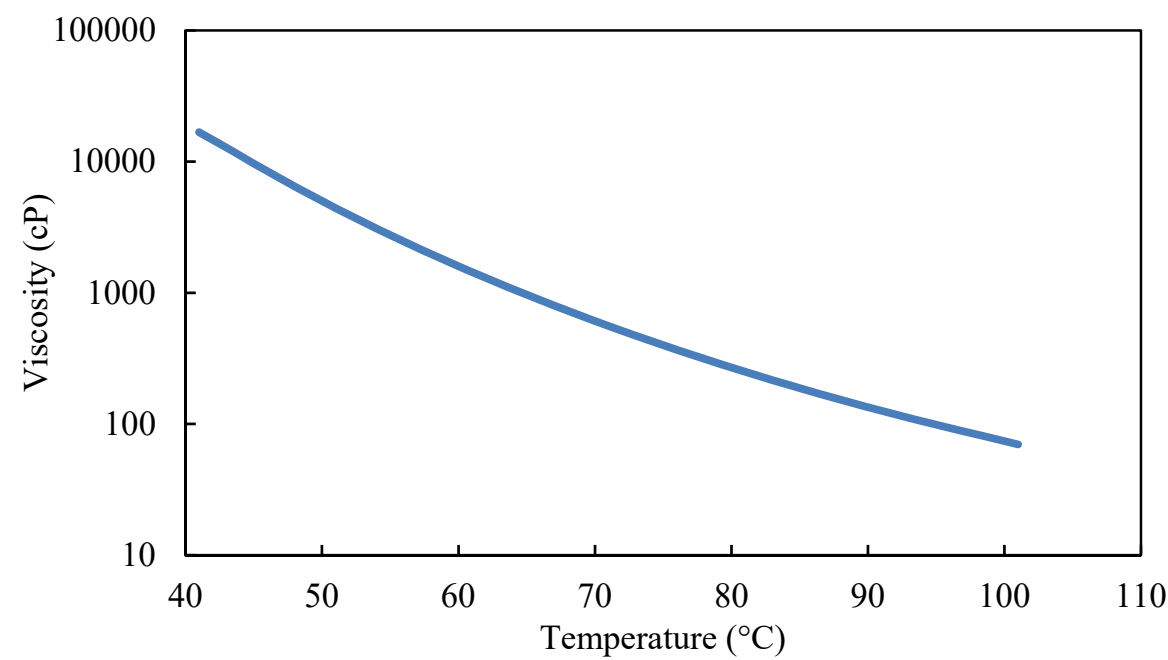

Figure 5. Viscosity $(\mathrm{cP})$ versus Temperature of low power of microwave heating

The power of microwave tuned at 180 watts. The heavy oil viscosity has been decreased from $4412.11 \mathrm{cP}$ at 51 $0 \mathrm{C}$ to $134.24 \mathrm{cP}$ at $900 \mathrm{C}$

\section{Conclusions}

The study has been demonstrated the application of microwave heating to reduce the heavy oil viscosity. Further, experimental results show that the heating rate is directly proportional with the output power of microwave and nano-ferro concentration. The threshold concentration of nano-ferro $\mathrm{Fe}_{2} \mathrm{O}_{3}$ was $14 \mathrm{ppm}$, which determined when the microwave was tuned at low power, 180 watts. The experimental results also described that time to reach a point of heating decreased as the concentration of nano ferro $\mathrm{Fe} 2 \mathrm{O} 3$ was increased, at the certain power of microwave. Further, an increase of temperature has also reduced the oil viscosity which could increase the oil production rate. In further, the increase of temperature could also affect the heavy oil recovery of a reservoir.

\section{Acknowledgements}

The authors are grateful to the Ministry of Energy and Mineral Resources, Republic of Indonesia, for providing the financial support to this endeavor.

\section{References}

Alboudwarej, H., Felix, J. J., Taylor, S., Badry, R., Bremner, C., Brough, B., ... West, C. (2006). Oilfield Review Summer 2006. Oilfield Review Summer 2006. Schlumberger.

Bera, A., \& Babadagli, T. (2015). Status of electromagnetic heating for enhanced heavy oil/bitumen recovery and future prospects: A review. Applied Energy, 151, 206-226.

Carrizales, M. A., Lake, L. W., \& Johns, R. T. (2008). Production Improvement of Heavy-Oil Recovery by Using Electromagnetic Heating. Society of Petroleum Engineers. http://dx.doi.org/10.2118/115723-MS

Chakma, A., \& Jha, K. N. (1992). Heavy-Oil Recovery From Thin Pay Zones by Electromagnetic Heating. Society of Petroleum Engineers. http://dx.doi.org/10.2118/24817-MS

Collin, R. E. (2001). Foundations for Microwave Engineering (2nd Ed). John Wiley \& Sons, Inc.

Green, D. W., \& Willhite, G. P. (1998). Enhanced Oil Recovery. Texas: Society of Petroleum Engineers.

Guo, B. (2007). Petroleum Production Engineering, A Computer-Assisted Approach. Gulf Professional Publishing.

Indriani, E. (2018). Stimulasi panas pada minyak berat yang menggunakan metode pemanasan elektromagnetik dan fluida nano fero. Unpublished doctoral thesis. Bandung: Institut Teknologi Bandung.

Pramana, A. A., Rachmat, S., Abdassah, D., \& Abdullah, M. (2012). A Study of Asphaltene Content of Indonesian Heavy Oil. Modern Applied Science. http://dx.doi.org/10.5539/mas.v6n5p64. 
Santoso, R. K., Rachmat, S., Resha, A. H., Putra, W. D., Hartowo, H., \& Setiawati, O. (2016). An Investigation of $\mathrm{Fe} 2 \mathrm{O} 3$ Nanoparticles Diffusion into Oil for Heat Transfer Optimisation on Electromagnetic Heating for Well Stimulation and EOR. Society of Petroleum Engineers. http://dx.doi.org/10.2118/182152-MS.

Shah, A., Fishwick, R., Wood, J., Leeke, G., Sean, R., \& Greaves, M. (2009). A review of novel techniques for heavy oil and bitumen extraction and upgrading. Energy \& Environmental Science, 3, 700-714.

\section{Copyrights}

Copyright for this article is retained by the author(s), with first publication rights granted to the journal.

This is an open-access article distributed under the terms and conditions of the Creative Commons Attribution license (http://creativecommons.org/licenses/by/4.0/). 